\title{
Towards an Evolutionary Understanding of the Current Global Socio-economic Crisis and Restructuring: From a Conjunctural to a Structural and Evolutionary Perspective
}

\author{
Charis Michael Vlados ${ }^{1}$, Nikolaos Deniozos ${ }^{1,2}$, Demosthenes Chatzinikolaou ${ }^{3} \&$ Michail Demertzis $^{4,5}$ \\ ${ }^{1}$ Department of Economics, Democritus University of Thrace, Greece \\ ${ }^{2}$ Department of Turkish Studies and Modern Asian Studies, National and Kapodistrian University of Greece, Greece \\ ${ }^{3}$ School of Law, Democritus University of Thrace, Greece \\ ${ }^{4}$ Department of Political Science and History, Panteion University, Greece \\ ${ }^{5}$ Department of Balkan Studies (Economy and Politics), University of Macedonia, Greece \\ Correspondence: Demosthenes Chatzinikolaou, School of Law, Post-Graduate Courses in South-Eastern Europe \\ Studies, Specialization in Economics, Democritus University of Thrace, Greece.
}

Received: March 12, 2018

doi:10.5430/rwe.v9n1p15
Accepted: March 27, 2018

Online Published: April 6, 2018

URL: https://doi.org/10.5430/rwe.v9n1p15

\begin{abstract}
The current global socio-economic crisis and restructuring reshapes the terms of study of the global dynamics as a whole. A new generation of interdisciplinary socio-economic research on the matter in question seems to be progressively emerging in international literature.

Against this background, it gradually emerges the understanding, that any attempt to interpret the individual contemporary socio-economic phenomena, which relate to the crisis and the attempt to restructure globalization, can only be inadequate and ineffective, since it fails to fully approach the current dynamics of globalization in synthetic, holistic terms.

In this direction, new interpretative approaches seem to intensify interpenetration and conceptual syntheses between the different fields of socio-economic sciences, in an increasingly unified perspective, by extensively "borrowing" -in a direct and indirect way- methods and theoretical "lenses" derived from system science, chaos theory, and evolutionary economics.

In the depth of this methodological rearrangement, according to the position put forward in the following paper, it is crucial that an effort is made to move from a conjunctural to a structural perception of the crisis. Ultimately, the great challenge for the field of study of global dynamics nowadays is the transition from the methodological principles of the traditional mechanistic interpretative method to a coherent and integrated evolutionary socio-economic perspective.
\end{abstract}

Keywords: global crisis, globalization dynamics, structural against conjunctural, systems science, chaos theory, evolutionary economics

\section{Introduction and Conceptual Precondition}

Despite a disappointingly slow pace, in the past few years and to this day, a new generation of fertile interdisciplinary research appears to emerge on the issues of the crisis and the restructuring of globalization (Abélès, 2008; Adda , 2012; Avant, Finnemore, \& Sell, 2010; Bayart, 2004; Bourg \& Papaux, 2010; Cerny, 2010; Cohen B. J., 2008; Cooper, Hughes, \& De Lombaerde, 2007; Dembinski, 2008; Golub, 2011; Jaffrelot, 2008; Kunz, 2011; Lordon, 2009; Mattli \& Woods, 2009; Orléan, 2009; Palan, 2000; Rainelli, 2011; Reinert, 2008; Sinclair, 2012). It seems to be increasingly absorbed in the consciousness of the international scientific community -and in a growing part of decision makers at all levels- the understanding that the study of the crisis and the restructuring of globalization itself (Aglietta, 2010; Aglietta, 2008; Amoore, 2002; Cohen D., 2011; Overbeek \& van Apeldoorn, 2012; Servet, 2010) can and should be a fertile and synthetic interdisciplinary research area (Augsburg, 2006; Klein J. T., 1991; Nissani, 1997; Bagchi, 1982; Chubin, 1976; Granovetter, 1985; Hariss, 2002; Stuart, 2005; Jacobs \& Frickel, 2009; 
Kanbur, 2002; Klein J. T., 1996; Klein J. T., 2006; Kleinberg, 2008; Schuurman, 2000; Sen, 2011; Sumner \& Tribe, 2008; Stehr \& Weingart, 2000; Weingart \& Padberg, 2014; White, 2002); an area that, under certain conditions, can lead to substantial cognitive progress in the wider field of socio-economic sciences and to create the necessary conditions for new policies to be articulated (Marchal, 1956).

\subsection{The Reflection of the Crisis to the Reconstruction of Globalization}

The interrelation between the global crisis and the re-construction of the world economy takes an important place for the further development of all the modern social sciences. Under the new globalization tensions, the old socio-economic knowledge barriers fall back while novel formations emerge: from the modern economics to political science (Ancel, 1936; Carroué, 2004; Chauprade, 2007; Fukuyama, 1992; Huntington , 2005; Kagan, 2003; Lacoste, 2006; Lacoste, 2014; Lévy, Poncet, et al., 2008; Luttwak, 1990; Strange, 1996), and from sociology (Abdelal, 2009; Anheier, 2007; Anheier, Glasius, \& Kaldor, 2001; Chase-Dunn \& Babones, 2006; Beaujard, Berger, \& Norel, 2009; Beck \& Duthoo, 2006; Bertrand, 2011; Bisley, 2007; Burawoy et al., 2000; Carroll, 2010; Chanda, 2008; Colic-Peisker, 2010; Douki \& Minard, 2007; Dufoix, 2012; Giddens, 2002; Grataloup, 2010; Graz, 2013; Grewal, 2009; Heilbron, Guilhot, \& Jeanpierre, 2009; Holton, 2008; Selchow, Kaldor, \& Moore, 2012; Keck, 2010; Lechner \& Boli, 2011; King \& Le Galès, 2011; Martel, 2010; Mattelart, 2007; Moore, 1966; Palmade et al, 1967; Robertson \& Scholte, 2006; Rosenberg J. , 2005) to the social psychology and the cultural studies (Bayart, 2010; Cardon \& Granjon, 2013; Cohoy, 1999; Cuche, 2004; Deroin, 2011; Dupin, 2017; Duterme, 2014; Florida \& Boyett, 2002; Hannerz, 1991; Koch \& Mattelart, 2016; Mattelart, 2009; Mattelart \& Neveu, 2008; Noiriel, 2007; UNESCO, 2015; UNESCO, 2013; Sassen, 2007; Simmons, Dobbin, \& Garrett, 2008; Warnier, 2008).

Therefore, without a clear insight of everything that the global dynamics and the crisis system includes/integrates, every attempt which strives to explain the separate and the layered socio-economic phenomena -as well the innovation and change management $(\mathrm{B} \lambda \dot{\alpha} \delta \mathrm{\delta} \delta, 2017)$ as consequences of globalization- it gives the impression that it cannot shake the explanatory inefficacy off. Indeed, without such a broad theoretical account, any of the separate scientific "developments" maintain a shadiness and an explanatory weakness.

In the long run, the innovation dynamics and the ongoing reconstruction of globalization define a so complex, critical and uncertain research anchorage ground which, by these means, reproduces its magnetism and, most especially, its fertility rate on the scientific knowledge.

\subsection{New Analytical Directions in the Study of the Dynamics of Globalization}

In the direction of renewing the study of the dynamics of globalization, the current crisis and its reorganization, we estimate that quite a few converging scientific fields/ research cradles/ schools of thought provide new analytical directions. And this in overall terms, in an attempt to enrich and renew the modern economic and administrative thinking.

In this study we will examine elliptically three of these. In particular, systemic theory, chaos theory and modern evolutionary and institutional economics. (See figure) 


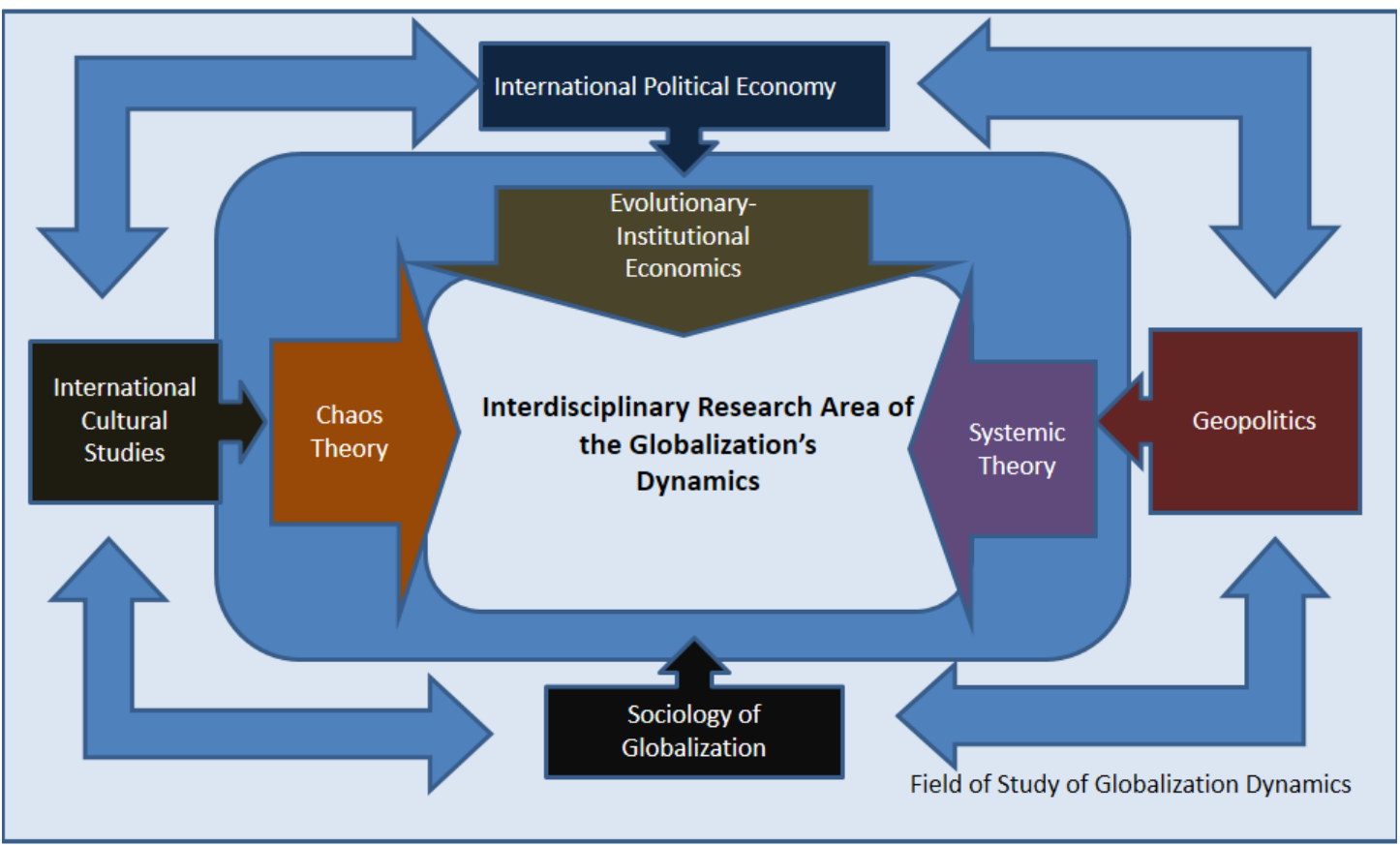

Figure 1. New directions at the globalization interdisciplinary research area

\subsubsection{The Systems Science and the Cybernetics}

The alleged systems science (or systemic theory) is the interdisciplinary scientific field which involves a shared way of thinking and a typical analysis, to develop a hypothesis for every kind of system: Social, biological, electronic, cognitive or metaphysical systems (Arbib \& Lecci, 1972; Ashby, 2015; de Rosnay, 2014; Forrester, 1980; George, 1976; Harlé \& Jouanneault, 1984; Pekelis, 1974; von Bertalanffy, 2012). The systemic theory follows a holistic approach when considering a situation, unlike the prevailing conventional logic which divides the problems to sub-sections and analyzes them separately. While the standard scientific tradition promotes an analytic, divisive, subtractive and linear problem solving, systems science renders a dynamic and a unifying explanation.

This reasoning, despite the late reheated interest, it has emerged since the interwar period. The most important note for though came up later, when Norbert Wiener publishes the book "Cybernetics: Or the Control and Communication in the Animal and the Machine", in 1948 (Weiner, 1961). This fact alone demonstrates the troublesome and challenging nature of the systemic theory to prevail in the scientific dialogue.

More specifically, cybernetics is a subset of the systems science and it is developing along the systems theory, but on a distinct base. Of course, the conceptual roots of this approach lie deep in the past of human intellect. As Aristotle put it first, "the whole is greater than the sum of its parts", that is why every system has unique properties, as a whole, which we do not see in any of its individual parts: These parts the system identifies only as parts of the whole. Therefore, a system defines a structural and unified set of elements (objects), a relationship between the elements and a relationship with their environment.

Under this approach we refer to the "system" when a structured field of specific "players" (agents of action) features interactions between them. According to Peter Senge, a system is an all-embracing entity, whose elements are assembled and co-evolve as they constantly exert mutual forces and act together for a final cause (Senge, 1994; Senge, 2006). The system consists, specifically, of multiple structured autonomous parts, each of them by some separate identity and behaviors, as well as with side by side co-determination interactions. Thus, an easy definition of the system comes forth by the idea of some interacting variables in an active network. That implies that every change of state in any of the links will, inevitably, bring changes to some other links of the system. The system, as a whole, as well through its parts, will always interact with the external environment. It will constantly contain subsystems of a lower complexity, as structural ingredients that work independently, but at the same time they interact with each other (Senge, 1999, p. 137).

In particular, a complex system is a non-linear structure, set by multiple interacting parts. Those kind of systems feature a strongly dependent and diverse character with respect to their parts, while less complex systems prove 
greater symmetry and clarity with respect to their complete establishments. The complex systems are self-organization hierarchies that show off emergent behaviors: novel behaviors deduced by their inter-relatedness and not by merely their isolated parts' attributes.

* The complex systems paradigm assists to understand the global crisis -and the ongoing reassemble of globalization forces- as a complex system: it is a dense network of endlessly affiliated variables that mutate themselves and the system through the various spaces, sectors and functional subsystems of the global system. (See figure)

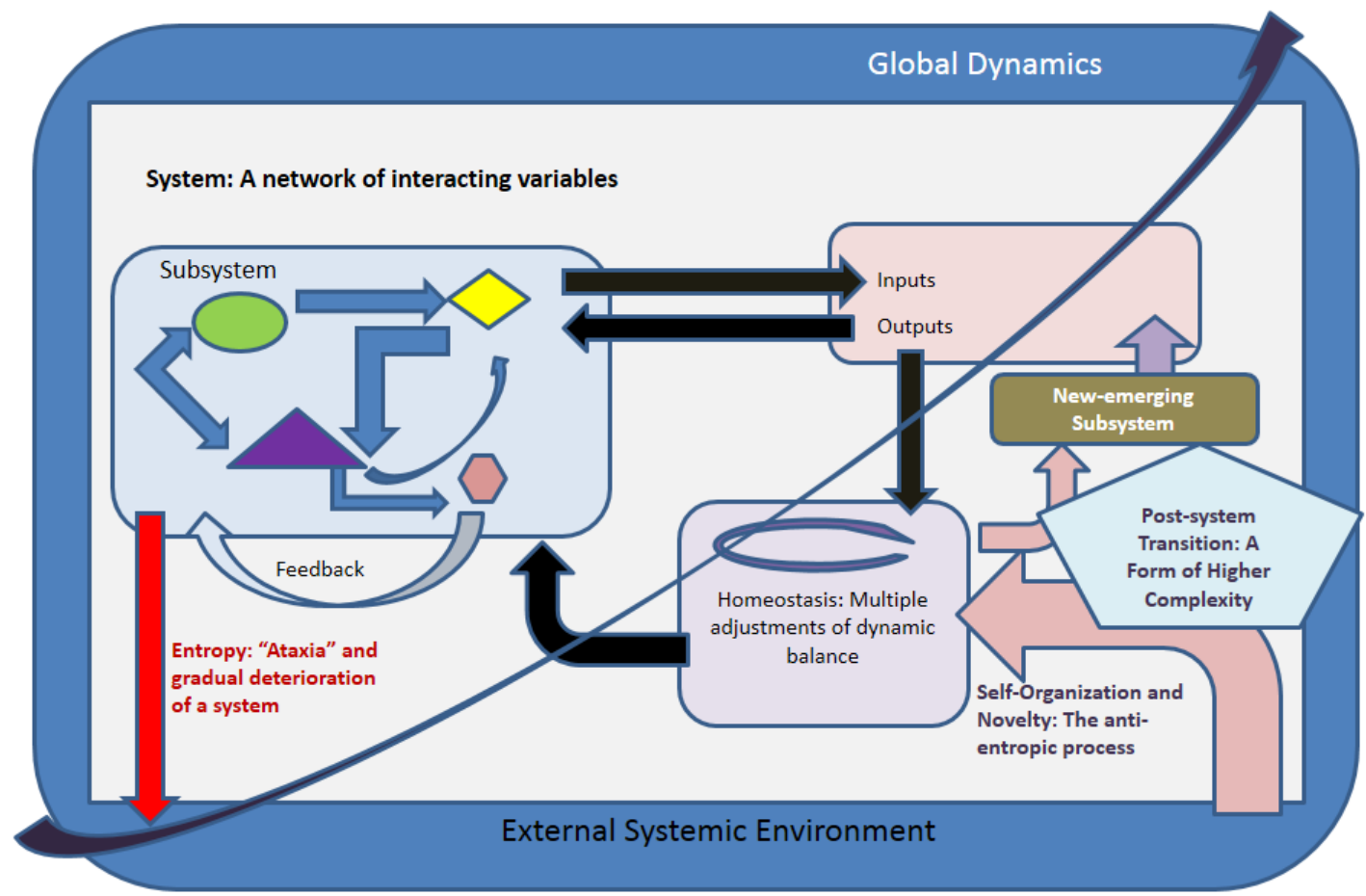

Figure 2. The systemic perspective of global dynamics

With respect to the cybernetics, we note that the fundamental elements of this approach are both the control and the communication. If to admit some deviations from the target and to do some corrective actions, the system requires some sort of information feedback to carry out a planned goal. The above actions represent a "negative feedback" which is a prerequisite for the control of the system. So there are four essential steering conditions towards a desired target:

A. A desired target set externally on a system.

B. A sensor that records the current state of a system.

C. A mechanism that compares the current situation with the desired one.

D. An Activator.

We have a negative feedback, in particular, when the re-feeding of an output leads to proper self-regulation of the system in order to eliminate the related output and to carry on with stability, despite external changes. The positive feedback, on the other hand, follows when the re-feeding of an output leads to proper self-regulation of the system in order to maximize the output in the future; something that enhances the possibility of divergence, diversity and change, so that the system reaches a new state of stability. In practice, without such feedback mechanisms, a system cannot maintain its status within its external environment and is unlikely to survive as a species in the face of environmental changes: it must adapt to, by setting new goals.

* Therefore, the cybernetics perspective enables us to better understand the width of innovation -in all varieties- within the current global restructuring, as a process of structural change of the continuous inputs 
and outputs of the individual subsystems of the global system, aiming to the dynamic stabilization, the self-regulation, and the adaptation to the new and emerging conditions.

Broadly speaking, systems theory provides a unifying framework to compare integrated systems, regardless of breaking the complex elements down to their structure, when taking into account the interactions of these fundamental ingredients. As we already mentioned, this "out of the box" thinking is holistic and represents the opposite method to test a system by reducing it to its structural parts (Battram, 2000).

* This approach marks as ineffective any simple and without a holistic view breakdown of the global crisis into some smaller pieces; the dynamics of gradual deterioration -the entropy of the world system itselfnever stop to act upon the overall evolutionary course of the historically successive models of growth.

On the opposite direction of the entropy, based on the systemic theory, there lies the self-organization. It is an anti-entropic mechanism which arises -either spontaneously due to natural laws or on purpose during self-generated phenomena- and works remedially, as a negative entropy, by causing the evolutionary reproduction of the systems, and by following a complex internal structure. This way, the transition of a system from a stage of low structural complexity to a stage of higher complexity, through the process of self-organization, is called post-systemic transition.

* And this analytic aspect of the systems theory proves to be very useful in terms of understanding the current global dynamics, because it enables us to regard the effort of escaping the current global crisis as an attempt of self-organization of the global system, through a post-systemic transition, to a state of higher complexity. And, of course, because it also makes the innovative action, in every aspect of globalization, absolutely justified in systemic terms: As a power of negative entropy and as the necessary effort of positive readjustment of the global system at all its interdependent levels.

Another fundamental dimension in systems theory is that of the autopoietic system. Autopoietic system is, in simple terms, a self-organized system, the parts of which are created by themselves (self-creation) and destroyed (self-destruction) in a continuous cycle, so the system maintains its dynamic state, despite the possible environmental changes. This process is called autopoiesis and autopoietic systems are defined as opposed to the allopoietic ones; that is, systems that produce and output components of other systems. Autopoiesis emerged as an application of the systems theory in biology, with the aim of defining life itself (Maturana \& Varela, 1980). Closely related to that is also the notion of homeostasis, which reflects the ability of an open system to regulate its internal environment to maintain a relatively stable state through multiple and mechanistically controlled adjustments of dynamic equilibrium (Katz \& Kahn, 1978).

* In this direction, in particular, the dimension of the persistent reproduction of the structures of the global crisis itself can be understood as an expression of the homeostasis of the already mature, in terms of evolution, system of the current globalization. From this point of view, the concept of "reacting to change", at each level of analysis, can be studied in greater depth and with greater completeness.

\subsubsection{The Theory of Chaos}

Notwithstanding the initial related ideas dating back to the beginning of the last century, the theory of chaos was formalized only after the mid- $20^{\text {th }}$ century, when for the first time it became apparent to some scientists that linear theory, the theoretical theory of that time, could not explain the observed behavior of some experimental phenomena. What was foreclosed in advance as a measurement inaccuracy -or as a mere "noise"- was considered by the theory of chaos as a complete constituent of the systems under study (Gleick, 1997; Kuhn, 1996).

In practice, Chaos Theory is an area that has its methodological roots in superior mathematics. Nowadays, however, it finds particularly fertile applications in various scientific disciplines, such as Physics, Biology and, of course, modern Economics and Organizational Science. Chaos Theory was created, in particular, to study the behavior of some non-linear dynamic systems. In these systems, small differences in the original conditions yield very different final results, making the long-term prediction very difficult to impossible in general. This is the case, although these systems are deterministic (or, in the most usual form, deterministic), which means that their future behavior is fully determined by their original conditions, without involving random parameters. And yet, the deterministic nature of these systems does not make them predictable. This behavior is known as chaos (See figure) 


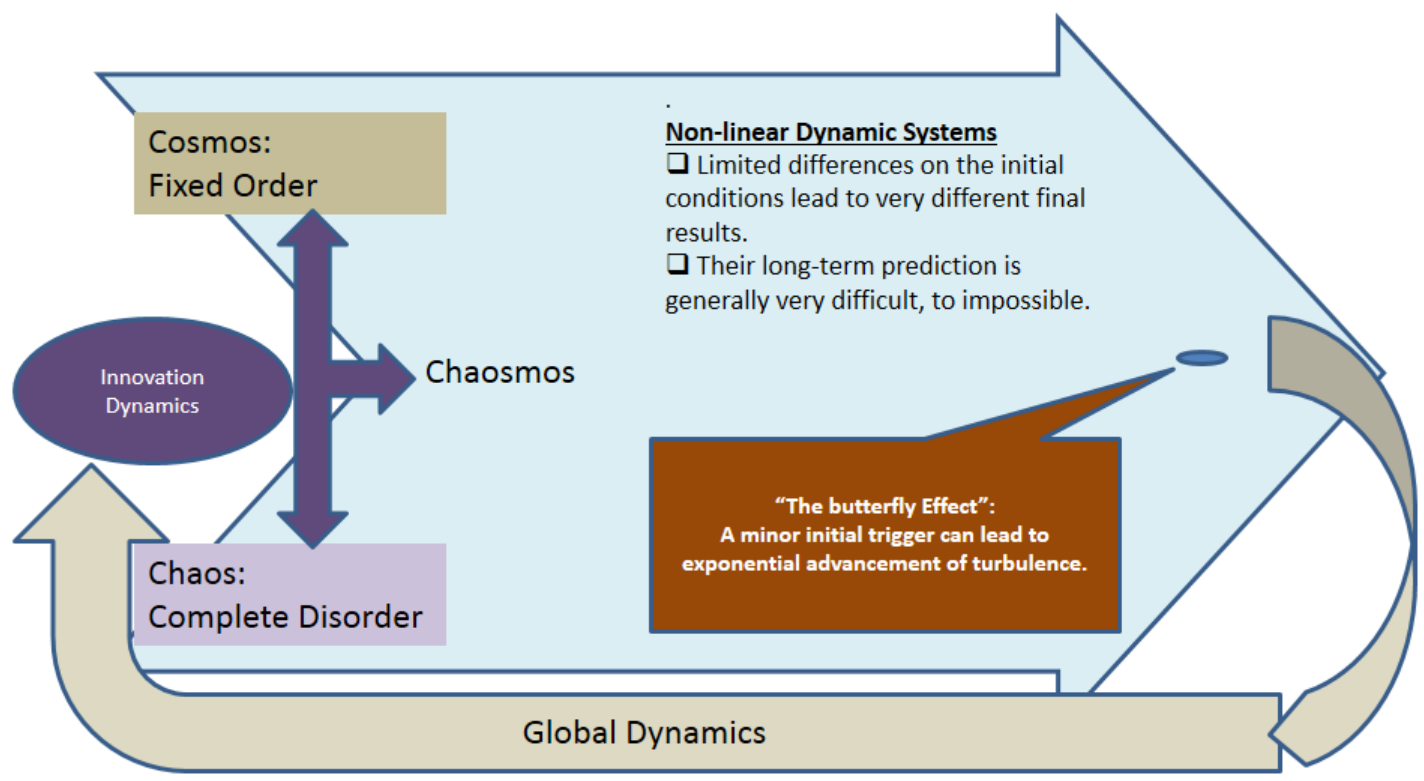

Figure 3. Elements of chaos theory and the innovation process, within the global dynamics

Conventional approaches to economics and administration, as we have already explained, perceive the "cosmos" as a stable linear system. Chaotics, on the contrary, perceives an organized activity as "Chaosmos", that is, as a composition of chaos (complete disorder) and cosmos (fixed order).

And according to Cornelius Castoriadis' view, the chaotic recovers and reconnects with the ancient Greek meaning of chaos as a void, abyss, infinite, from which the world emerges (Castoriadis, 1997). To the mathematical meteorologist Edward Lorenz, founder of this theoretical platform, Chaos is revealed "when the present determines the future, but the approximate present does not approximately determine the future".

Chaotic behavior is also observed in socio-economic systems and, in particular, in the phase of their crisis. More generally, systems with mathematical chaos are deterministic and therefore have a sort of order, are arranged in a sense. Of course, this technical use of the term "chaos" disagrees with the spoken word, in which chaos denotes the complete lack of order.

* In practice, this particular theoretical perspective helps us to understand the global crisis in terms of an inherently chaotic system, as a situation open to unpredictable developments and without a prescribed end.

In its general use, the term "chaos" means a state of disorder (Hasselblatt \& Katok, 2003). However, in the theory of chaos, this term is defined more precisely. Although there is no universally accepted mathematical definition of chaos, a relatively commonly accepted definition (Devaney, 2003) says that in order to characterize the behavior of a system as chaotic it must have the following properties:

$>$ It must have a significant sensitivity to the original conditions.

$>$ It must be topologically transient.

$>$ It must be structured as a dense set of interactions consisting of all the constituent system trajectories.

In particular, the scientists who developed the Theory of Chaos, to study the way in which events unfold on the basis of an initial state and certain deterministic assumptions, have succeeded in showing in particular that a small initial trigger can lead to exponential development of turbulence. Sensitivity to the original conditions is also known as the source of the "butterfly effect", which is named after the work that Edward L. Lorenz delivered in 1972 to the American Association for the Advancement of Science, entitled "Predictability: Does the Flap of a Butterfly's Wings in Brazil Set Off a Tornado in Texas?". The flap of the wings represents, in particular, the realization that a small change in the initial state of the system can cause a chain of events leading to large-scale phenomena. If the butterfly had not hit its wings, then the orbit of the system could have been very different. That is, according to this view, an infinitesimal change in the flow of events leads, over a period of time, to a development of the system's history 
dramatically different from what would have taken place had that change not occurred. So, Philip Kotler and John A. Caslione put it: "the butterfly effect" is observed because the world in which we live is an increasingly interconnected, interdependent globalizing world that accelerates its "globalization". Here, all peoples, all governments, all businesses, all the actors of actions ultimately are intertwined to some extent, and the impact of turbulence on each of them will be felt to some extent by others within the globally connected environment (Kotler $\&$ Caslione, 2009).

* Finally, this chaos theory helps us to understand that in a system such as that of modern world dynamics, small changes can bring enormous structural changes within it, leading to an increasingly complex horizon of developments. And that it is possible for an innovation -a simple "butterfly flight"- to have drastic structural consequences on the whole of the global system.

\subsubsection{The Perspective of Evolutionary and Institutional Economics}

The previous theoretical guidelines help to further move from a narrow, mechanistic perception of the world, to an "ecosystemic", "open" and holistic perception that highlights interdependence, self-organization of systems, time, history, probability, the possibility of emergence of the new, as essential traits of our world (Toulmin, 1985; Toulmin, 1992).

In the background, they help us to approach the perspective of the evolutionary model of understanding the socio-economic phenomena surrounding us. In particular, the evolutionary model in the social sciences can be understood as the scientific methodological framework which attempts to apply in the study of socio-economic phenomena the principles of study governing the appearance and reproduction of the biological types in the earth's ecosystem through the principles of genetics diversification and natural selection. In the 1980s, mainly, most of the attention was drawn by the evolutionary models that were influenced by the systemic theory and cybernetics, which we examined shortly before. This gave rise to a tendency to interpret systemic self-organization as the application of the principles of evolution to all kinds of systems and not only biological ones.

In particular, evolutionary economics is now part of the central backbone of modern economic science (Friedman, 1998; Friedman, 1998), yet retaining several elements of a fertile "heterodoxy" that are inspired, in particular, by evolutionary biology. The evolutionary economics -and in particular the institutional economics sector- study the complex socio-economic interdependencies (Rosenberg \& Birdzell, 1987): Competition, growth, structural changes, in an environment of permanent lack of resources, by addopting a "living", "organic" methodological perspective, we might say. Evolutionary economics is concerned with the study of processes that transform the economy and society, with reference to both business and industry, employment, production, commerce and distribution, social stratification and social mobility, through the actions of the various actors / players within the structures where they are activated.

* This theory serves as a reason of seeing the real dynamics of globalization by the "modus operandi" of biology because the focus on the natural selection, the survival, the development and the reproduction of both the players and the structures (of globalization) becomes the inherent basis of the system. In this context, the structural change process and the innovation understands the "organic" within the enduring evolution.

The Evolutionary Economy holds the necessary emergence of technological and institutional innovation inside its hypothesis, by the creation, the experiment, the rejection or succession of various ideas and practical applications, which give more powerful natural selection (value) in comparison to the sacrifice (cost) and to the competitive alternatives. Consequently, the focus shifts to the endogenous off-balance processes which change the economy. The choices of the different actors (players) force these structural changes to the outward structure of the system.

* That logical thinking clears two restrictions: the first "how things hold their present sense" and the second "a thing is going to keep its intolerant fate tomorrow": All things change deeply and evolve, constructing a path that includes successive and irreversible critical points of choice (B $\lambda \alpha \dot{\delta} \delta \varsigma \varsigma, 2006)$. (See figure) 


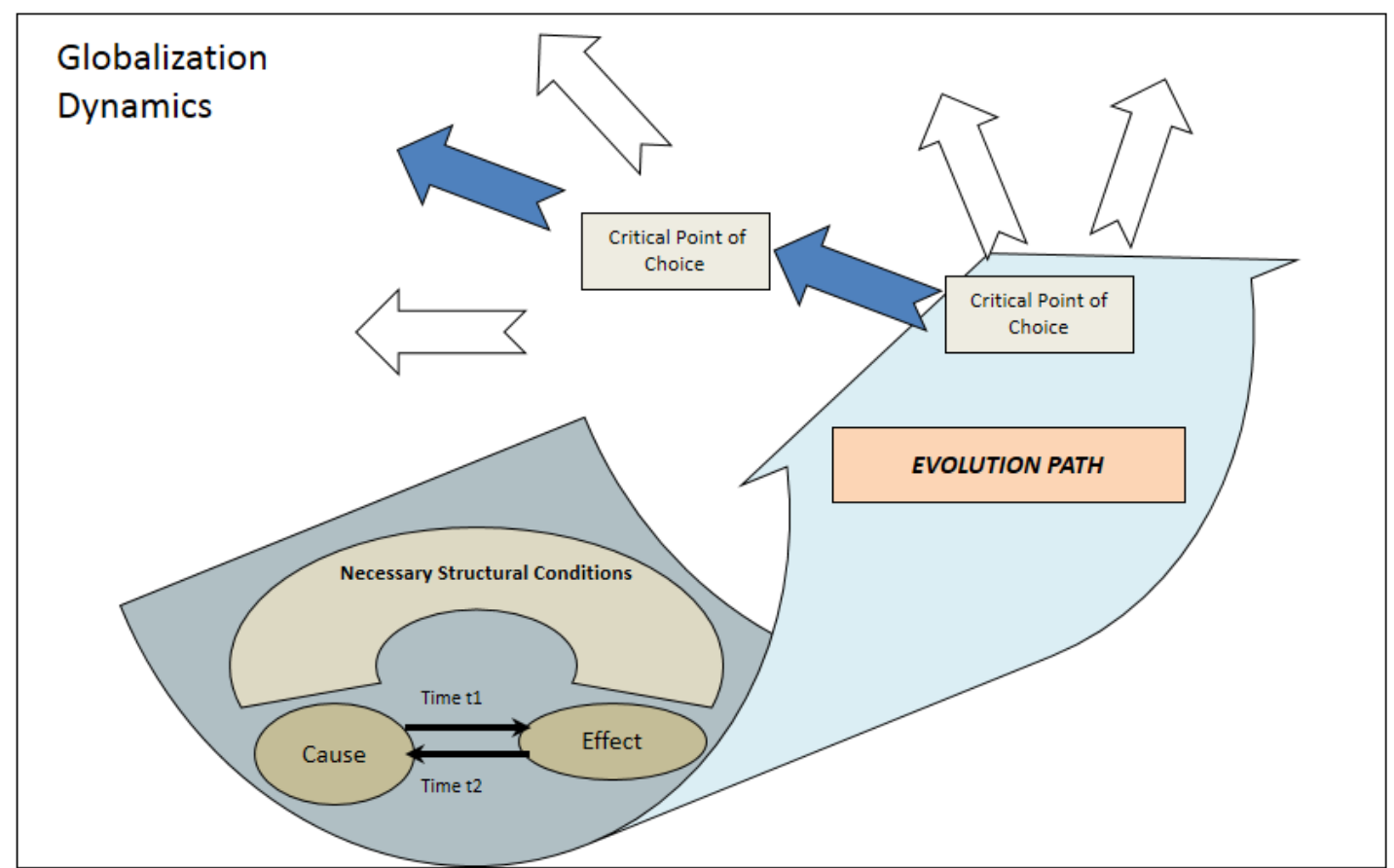

Figure 4. The evolution path of a socio-economic system, within the globalization dynamics (B $\lambda \alpha \dot{\delta} \delta \mathrm{o}, 2006)$

Is there anything static or eternal within the constant change of capitalism and the dynamics of global economy?

Under the light of the wide historical experience, it is clear that the only given regarding the dynamics of capitalism is its continuous expansion, the constant re-synthesis of its potential and the continuous application of innovations at every level of action. The structural changes take place within every spatial, institutional, regulatory, strategic, technological, organizational and functional level. Capitalism cannot exist without invariably expanding, as well as changing, reconstructing and transforming the structure, without, ultimately, the disruptive innovations. In conditions of "containment" and / or "restraining" of this restructuring dynamics, its profitability is shrinking and its central engine -the competitive business- weakens and loses its evolutionary dynamism. For this, it is crucial to understand that the capitalistic profitability itself -and the innovative action that is always behind it-can only be perceived as an evolving dialectical socio-economic reality (B $\lambda \alpha \dot{\alpha} \delta o \varsigma, 2006)$.

\subsection{Towards a Systemic and Evolutionary Understanding of the Dynamics of Globalization}

On the basis of the above, we can distinguish some fundamental findings of the systemic and evolutionary

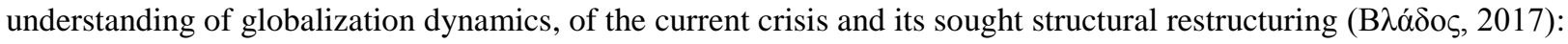

$>$ There have been, there are and there always be profound upheavals in the evolution of the global capitalist "game": This is the very deepest nature of capitalism.

$>$ The globalization game can only be transformed, progressively and unceasingly, in terms of dense systemic rules.

$>$ The only thing that remains constant in relation to global dynamics is the uninterrupted evolutionary logic that governs it entirely.

$>$ We should never, in any case, isolate ourselves from a historical perspective while trying to understand the evolutionary movement of world capitalism.

$>$ The study of globalization dynamics must be based on the historical, geographical and institutional specificity of the individual socio-economic phenomena included in its analysis.

$>$ There can be no predetermined and supposedly repetitive "small cycles" for the global capitalism, without the deeply structural and qualitative transitions and reversals.

$>$ Multi-faceted innovation, at each level of action -and the required management of change- define the most critical points for the overall evolutionary dynamics of the global economy to be structured upon. 
We therefore estimate that only by using the latest methodological guidelines -which we have attempted to present elliptically as here- the study of globalization dynamics, in the phase of its current crisis, could be analyzed in detail. On the contrary, we estimate that by insisting on using the older, linear, simplistic and one-dimensional analytical models we are led to a loss of critical response time in relation to the current configuration and the broader prospect of exiting this crisis.

In the long run, as we fail to approach the dynamics of globalization in an evolutionary-open way -on how it is synthesized and how it is unceasingly crafted by nature- we will continue to get tangled up in the theoretical interpretative terms while paying an ever greater cost of adaptation, as individuals, as social groups, as whole socio-economic formations. For the above mentioned reason, we estimate that, in general, the transition from a conjunctural to a structural-evolutionary perception of the global crisis is now becoming absolutely necessary on the field of the crisis study.

\section{The Conjunctural and Structural Perception of the Crisis}

The first major obstacle for any attempt to fruitfully approach the current crisis of globalization, on behalf of many contemporary superficial approaches, is the self-trapping in fragmented, overly narrowly defined and ultimately interpretive deadlock analytical platforms (Business News, 2017; Rowlatt, 2012).

$\square$ The partial comes, completely arbitrarily and in a totally wrong way, to substitute the total.

$\square$ "Globalization" becomes superficially perceived as a mechanical sum by, to a large extent, incoherent pieces and not as a historically evolving and organic whole.

$\square$ Mechanistic logic, conceptual legacy of the "neoclassical" theoretical tradition, weakens any attempt for the evolutionary perception of the phenomena that lie in the root of the global dynamics (Lowe, 1951).

Behind all these, lies the incomplete and superficial perception of the very concept of crisis.

\subsection{What Does Crisis Mean? The "Fire in the Forest"...}

But what does crisis mean, above all, beyond its specific content in terms of globalization? The notion of crisis, though strange to some, cannot be taken for granted: it is ambiguous, complex and multi-faceted. It can mean, at the same time, a wide variety of heterogeneous things and situations. Indeed, by going even deeper to the broader cultural background of socio-economic reality, the concept of crisis manages to receive a differentiated connotation and direction.

In total terms, however, we could say that every crisis is the acute manifestation of a set of problems that results in the drastic overthrow of the "ordinary" evolution of things. And, of course, most often, the crisis is manifested through "chain explosions", as each problem creates the conditions for other problems to emerge around it.

More specifically, in economic science, although the concept of crisis is fundamental -at least since the time of Marx and his "descendants"- it does not cease to be shadowy and contradictory. (Aydalot, 1984).

Of course, a very important issue is when we think there is indeed a crisis. When there is a big blow to the economy (cause-crisis) or when the unpleasant consequences of an event become widespread (result-crisis)? The first case requires a clear definition of a specific quantitative "crisis threshold", which obviously varies according to the seasons and the nature of each problem (such as debt, unemployment, inflation, external deficit, etc.). In the latter case, an assessment of their impact and duration is of course needed in critical areas such as production,

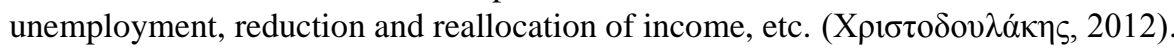

Even if we could set unquestionable and non-historical quantitative thresholds for determining the crisis, how could we, based on these, conceive indeed such a wide variety of complex evolutionary phenomena of crisis? How could we analyze in detail the phenomena of any socio-economic crisis which, first of all, are constituted by deep qualitative transitions that are often quantitatively "silent" before their eruption?

Beyond these, as Dani Rodrik (Rodrik, 2011) rightly points out, economists tend to focus too much on solutions regarding the "last crisis". On the contrary, they do not adequately study existing tensions that may lead to the next crisis. And of course, their interest should not focus solely on quantitative data on market prices or profitability.

Let's move on with something simpler. Let us bring to mind, for the sake of convenience, the image of a relatively simple, easy-to-understand and trivial form of crisis: Let's say a fire of a forest. Does everyone understand, act and react the same way against such a crisis?

No, no matter how strange it sounds. There are radically different ways to get to grips even with a simple fire. 
In a deeper sense, we can say that, even in this simple case, the two main "views" of perceiving and defining the concept of any kind of crisis appear: The conjunctural and the structural. These will be briefly examined below.

\subsection{The Crisis Under the Conjunctural View}

In this "perspective" the crisis is perceived as something extraordinary, as something superficial: As an occasional overthrow of the balance of things, as something "unnatural" but assimilable by the current system of things and, finally, passable. The crisis comes, is treated by "firefighting" and, ultimately, is "overcomed". Then, everything continues their predetermined course, within the framework of the "previous status" of things and relationships.

In this perspective, the crisis is considered to have an "exceptional" and "unexpected" character and is structured by specific, unspecified events - or a series of events- that create high levels of uncertainty and threat (or viewed as a threat) regarding the high priority goals of an organization, of every level and kind. Through this way of understanding, the event of the crisis is always:

\section{$>$ Unpredictable}

$>$ Creates a temporary shock and uncertainty

$>$ Considered as a threat and leads to a drastic reduction in performance regarding the important goals previously set (Seeger, Sellnow, \& Ulmer, 1998).

Within the range of this view of the crisis they fall, moreover, all the partial disturbances in the greater context of perceiving any socio-economic "stable equilibrium". In these cases something usually exogenous (created "outside" the system) is incidentally destabilizing the balance. But the balance is finally restored and everything continues to work with the "old logic", as with the case of natural market-equilibrium (according to the usual slopes of the demand and supply curves) described in any microeconomics manual of a first year student.

It is clear, however, that in terms of the so-called crisis management, "crisis" is perceived completely differently than against an economic crisis.

At the forefront of this field, the Harvard Business School (Harvard Business Review, 2008), in a relative handy version, notes: "Crisis is a change -a sudden or ongoing- that causes a pressing problem that needs to be addressed immediately". And it identifies the following stages in crisis management, according to the following sequence:

1. Preventing the crisis

2. Preparing for crisis management

3. Recognition of the crisis

4. Restraining the crisis

5. Tackling the crisis

6. Lessons learned from the crisis

Especially in the last step, concerning the lessons learned from the crisis, this method proposes in particular:

- Reviewing crisis management mode: Where you program the review time soon enough for the participants of the management to remember the details -but also long enough after the event for the emotional calmness to be restored.

- Planning for future crisis management: Where you build a new plan to learn from your experience.

- Monitoring the results: Where you just observe the results of the changes you made after the crisis.

Of course, this is a reasonable approach. But there is nothing structurally coherent, anything historical and evolutionary in interpretative and predictive terms in this "practical" perspective. The deeper exploration of the crisis pattern remains untouched; neither the deeper "why" nor the specific "how" of the crisis are illuminated in this way. Of course, in such a serial and superficial perceptual orientation, it is difficult to end up with anything more than a narrowly repetitive understanding of reality and, by extension, without realizing its deeper structural content, thus remains the exposure to the strong possibility of a new similar crisis.

But let's go back to our example, to the burning forest, and apply here the conjunctural perception of the crisis. How is the fire treated? In the conjunctural rationale, the firefighting vehicles will, of course, rush and the fire will eventually go out. The forest will be more or less burnt, but it will re-grow "like in the past", everything will go back as it used to be, and in a few years everything will be forgotten.

And what were the causes of the fire in this conjunctural perspective? 
Just a lit cigarette or a worn power cable or some kind of overheating by the strong sunshine of the day. "Bad luck", in two words.

\subsection{The Structural Perception of the Crisis}

In this second visual perception and interpretation, the crisis is conceived as something deeper, as something evolutionary necessary, as something organic and as something that brings unavoidable structural changes to each system that leans. Thus, in this way, the crisis is captured as something endogenous, inevitable, and ultimately, normal.

The crisis comes, is overcome and is once more overcome, but always taking with it the "old status" of things. Nothing then goes on like before, under the previous "regime". Always, the "old regime" of things necessarily collapses and is replaced by a new one. In this second approach the crisis refers to something that resembles the irreversible death but also the inevitable birth: By the birth of the new and the death of the old, at the same time.

Here is the mutation involving irreversible reversals that are placed in the logic of evolution. And here comes the situation where the rule is transformed, one class fades and another is formed (Passet, 1996).

In the example of the burning forest, here again the firefighters will rush again and again the fire will go out at some point. But, in this approach, there is the awareness that the burnt forest will never grow back "the same way" like in the past. Many of its old flora and fauna species will fail to survive and will become extinct, new species will migrate, new populations will develop, new ecosystem balances will emerge, and in a few years the new forest will necessarily be significantly different than the one that got burnt.

But even the approach to the causes of the fire clearly differs in this structural "standpoint".

Here is not just the lit cigarette, the worn cable or the dry grass that overheated, but deeper, maybe the poor mentality of the passerby who smoke or even the outdated technology of the local electric wires, or perhaps the poor cleaning woods from the dry branches and greens. There was no bad weather, the fire was no misfortune: on the contrary, it was an event that would happen sooner or later and, in these circumstances, just a matter of time.

\subsection{The Basic Differences Between the Conjunctural and Structural Aspects of the Crisis}

The difference between the two "optics" becomes clear:

* The conjunctural view of the crisis is partial, fragmented and "over-optimistic"; everybody hopes for a quick exit and return to old regularity.

* The structural view of the crisis is complete, coherent and, say, "stoic"; everyone here know how to expect the maturity of evolution. (See figure)

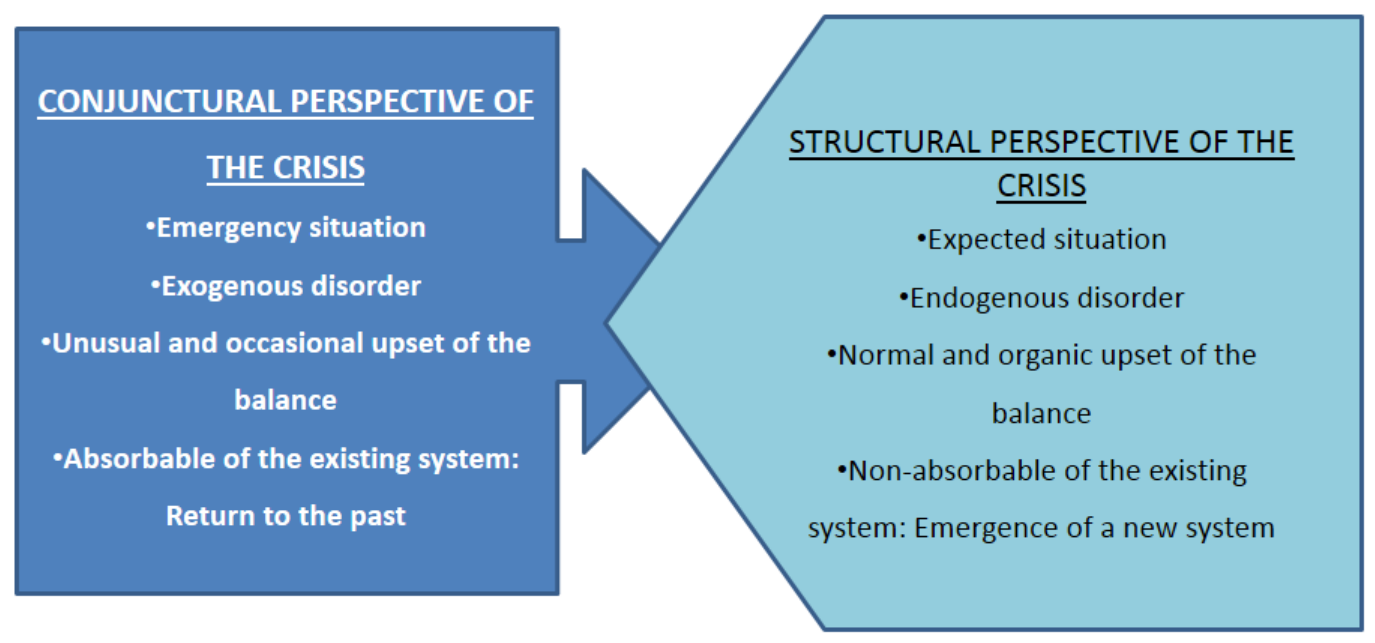

Figure 5. The conjunctural and structural view of the crisis (B $\lambda \alpha \dot{\delta} \delta \mathrm{o} \varsigma, 2017)$ 
Surprisingly in our eyes, in the rapid and total upheaval we are experiencing today, the "over-optimistic", conjunctural way of perceiving the crisis continues to dominate today, to the vast majority of the community of scholars and managers.

But why, you will ask?

Maybe because as humans we have an innate psychological / behavioral inclination towards the reassurance and sense of security provided by the familiar. Perhaps, because a valid understanding of the structural aspect of the crisis requires a variety of ideological overturns that the vast majority of people -scholars and managers- does not know, does not want and cannot stand it.

The opinion of the writers is that only in the second direction of understanding the concept of crisis -that is, the structural, historical and evolutionary view of the crisis- can be recognized its structural and deeper subversive content. (Aoki, 2001; Billaudot, 1996; Boyer \& Durand, 1998; Boyer, 2004; Coriat, Petit, \& Schmeder, 2006; Esping-Andersen, 1999; Gadrey \& Jany-Catrice, 2012; Lorenz \& Valeyre, 2004; Perez, 2003; Théret, 1992). And precisely because this direction of understanding is much less "in fashion" nowadays, it is advisable to detect and try to clarify soon some of its less widely understood points.

\subsection{The Conceptual Prerequisites for a Structural Understanding of the Crisis}

In our view, the concept of a structural crisis in socio-economic terms must always be based, as minimum, on the following conceptual assumptions (B $\lambda \alpha \dot{\alpha} \delta o \varsigma, 2016)$ :

- The crisis always involves complex, organic-type systems.

A simple system, a simple "machine", never comes into crisis: It simply presents a "corrective damage", let's not confuse it. (Venette, 2008).

- Crisis has always been a matter of urgency.

It must be dealt with as quickly as possible because the overall systemic stability and viability of the system is at imminent risk.

- Crisis rarely destroys directly the affected system.

But it reduces drastically -and often in a worsening way- its operational effectiveness in achieving its previously defined goals (Mitroff \& Silvers, 2009).

- Crisis has always, necessarily, a restructuring content.

The post-crisis situation cannot be assimilated to the previous regime.

- Crisis has always an evolving character.

It is not limited to only some functions. It extends, obviously or implicitly, via "metastases" on all sides of the system-organism.

And, deep down:

- The crisis is, in the end, a "normal phase" in the evolution of each organism / system

It can lead to death or create the necessary conditions for its renewal, eliminating its inadequate, diseased or dead "cells". It is not a pleasant phase, but it is an evolutionary phase.

As we have emphasized before, in any case, the crisis cannot be fully explained by the tools of the former physiological state. Addressing it always requires a radically renewed understanding and a completely new way of adapting to its dynamics.

\section{Concluding Remarks: For a New Way of Reading the Global Crisis and Restructuring}

As all now show that we are living in the emergence of a new world reality, the old economic vocabulary, the past dominating interpretative platforms, the dominant theoretical "lenses", are often disappointing. How to describe, understand and build the new, when limited to the theoretical "tools" of the old? It is not, in fact, possible.

Of course, the necessity of renewing socio-economic interpretative perspectives must not surprise us. Socio-economic science itself could not remain unaffected by the crisis. History shows that the crisis itself "irritates" and renews socio-economic thinking and science at all times. The central issue is now the deeper renewal of the conceptual and analytical arsenal, in general, of the socio-economic science, so that it can describe, interpret and predict the new emerging world 
Is that easy? We do not think so. The vast majority of today's economy, society and administration people, either at practical or theoretical level, are often unconsciously "trained" for a long time in a static -or, at best, comparatively

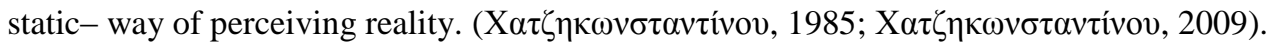

This way of perceiving reality, however, hides very serious explanatory dangers. In practice, we feel we need a shift towards a historical, systemic and structural understanding of the phenomena that concern us. In the background, we need to move from a mechanistic perspective to a structural and evolutionary perspective of global dynamics and its components. In this direction, the absolutely necessary methodological redirects that are required, according to our point of view, are based and can be summarized in the following fundamental realizations:

* Nothing in a socio-economic system "falls out of nowhere".

* Everything, always, is the result of pre-existing conditions.

* Everything is born by its structural past and the systemic interactions that incubated it.

* Even the seemingly extreme events behind the crisis hide the normal forces and processes that have hatched them.

* The historical understanding of economic phenomena, within their specific socio-economic context, is always absolutely necessary.

The above-mentioned realizations guide us away from the methodological principles of the mechanistic interpretative method, in practice and effectively, and push the socio-economic thinking into an evolutionary perspective. (See figure)

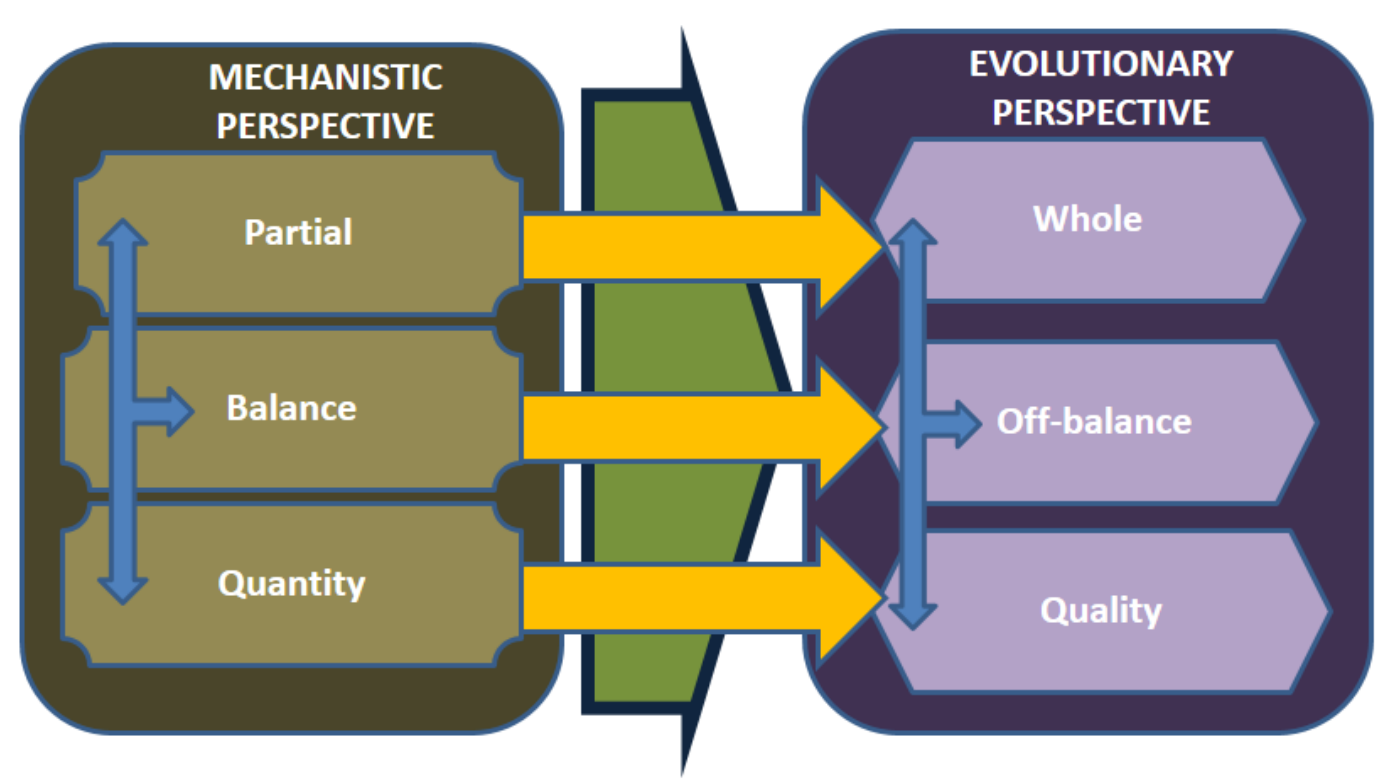

Figure 6. The need for a new approach to the global crisis and its reconstruction: moving from a mechanistic to an evolutionary perspective (B $\lambda \alpha \dot{\delta} \delta \varsigma$, 2017)

In particular, we believe that there is now an immediate need for an open interdisciplinary evolutionary perspective that will replace:

* The fragmentation in the analysis of individual socio-economic dynamics with a unifying spirit.

* The focus on balance with a spirit that will give substantial interpretive weight to the continuous reproduction of the imbalance.

* The over-concentration in the accumulation and variance of quantities with a spirit that will deepen the analysis of qualitative transformations, usually occurring silently beneath the surface of the phenomena. 
By choosing an evolutionary perspective, the meaning of the globalization crisis and the exit from it, ceases to be "by nature" an "incoherent question" that cannot be answered in a valid and comprehensive way. In this analytical orientation, the attempt for a coherent answer is not "by definition impossible" and is proved anything but useless.

From this point of view, we find perfectly legitimate the relocation and deepening of the relevant questions, both theoretical and practical, into a new, holistic, interdisciplinary and systemic basis for a new generation of field research.

\section{References}

Abdelal, R. (2009). Capital Rules: The Construction of Global Finance. Harvard University Press.

Abélès, M. (2008). Anthropologie de la Globalisation. Payot.

Adda , J. (2012). La Mondialisation de l'économie. Paris: La Découverte.

Aglietta, M. (2008). La crise: Pourquoi en est-on arrivé là? Comment en sortir? Michalon.

Aglietta, M. (2010). La crise: Les voies de sortie. Michalon.

Amoore, L. (2002). Globalisation Contested: An International Political Economy of Work. Manchester University Press.

Ancel, J. (1936). Geopolitique. Paris: Delagave.

Anheier, H. K. (2007). Introducing 'Cultural Indicator' Suites. In H. K. Anheier, \& Y. Raj Isar, Cultures and Globalization: Conflicts and Tensions (The Cultures and Globalization Series). SAGE Publications Ltd. https://doi.org/10.4135/9781446214671.n34

Anheier, H. K., Glasius, M., \& Kaldor, M. (2001). Global Civil Society. Oxford University Press.

Aoki, M. (2001). Toward a Comparative Institutional Analysis. MIT Press.

Arbib, M. A., \& Lecci, A. (1972). The Metaphorical Brain: Introduction to Cybernetics as Artificial Intelligence and Brain Theory. John Wiley \& Sons Inc.

Ashby, W. R. (2015). An Introduction to Cybernetics. Martino Fine Books.

Augsburg, T. (2006). Becoming Interdisciplinary: An Introduction to Interdisciplinary Studies. Kendall Hunt Publishing.

Avant, D. D., Finnemore, M., \& Sell, S. K. (2010). Who Governs the Globe? Cambridge University Press. https://doi.org/10.1017/CBO9780511845369

Aydalot, P. (1984). Crise et espace. Paris: Economica.

Bagchi, A. (1982). The Political Economy of Underdevelopment. Cambridge University Press.

Battram, A. (2000). Navigating Complexity. Spiro Press.

Bayart, J.-F. (2004). Le gouvernement du monde. Une critique politique de la globalisation. Fayard.

Bayart, J.-F. (2010). Les études postcoloniales, un carnaval académique. Afrique contemporaine (No. 235), pp. 149-152. https://doi.org/10.3917/afco.235.0149

Beaujard, P., Berger, L., \& Norel, P. (2009). Histoire globale, mondialisations et capitalisme. Recherches.

Beck, U., \& Duthoo, A. (2006). Qu'est-ce que le cosmopolitisme? Editions Aubier.

Bertrand, R. (2011). L'Histoire à parts égales. Récits d'une rencontre, Orient-Occident. Le Seuil. https://doi.org/10.14375/NP.9782021050172

Billaudot, B. (1996). Regulation et Croissance: Une macroéconomie historique et institutionnelle. In Théorie Sociale Contemporaine. L' Harmattan.

Bisley, N. (2007). Rethinking Globalization (Rethinking World Politics). Palgrave.

Bourg, D., \& Papaux, A. (2010). Vers une société sobre et désirable. Presses Universitaires de France. https://doi.org/10.3917/puf.brg.2010.01

Boyer, R. (2004). Théorie de la régulation. La Découverte.

Boyer, R., \& Durand, J.-P. (1998). L'après-fordisme. Paris: Syros. 
Burawoy, M., et al. (2000). Global Ethnography: Forces, Connections, and Imaginations in a Postmodern World. University of California Press.

Business News. (2017, June 27). Thomson Reuters. Retrieved from Fed's Yellen expects no new financial crisis in 'our lifetimes': https://www.reuters.com/article/us-usa-fed-yellen/feds-yellen-expects-no-new-financial-crisis-in-our-lifetimes-i dUSKBN19I2I5

Cardon, D., \& Granjon, F. (2013). Médiactivistes. Les Presses de Sciences Po.

Carroll, W. K. (2010). The Making of a Transnational Capitalist Class: Corporate Power in the 21st Century. Zed Books.

Carroué, L. (2004). Géographie de la mondialisation. L'Information Géographique, 68(2), 191. Retrieved from www.persee.fr/doc/ingeo_0020-0093_2004_num_68_2_2945_t1_0191_0000_3

Castoriadis, C. (1997). Anthropology, Philosophy, Politics. Thesis Eleven, 49(1), 99-116. https://doi.org/10.1177/0725513697049000008

Cerny, P. G. (2010). Rethinking World Politics: A Theory of Transnational Neopluralism. Oxford University Press. https://doi.org/10.1093/acprof:oso/9780199733699.001.0001

Chanda, N. (2008). Bound Together: How Traders, Preachers, Adventurers, and Warriors Shaped Globalization. Yale University Press.

Chase-Dunn, C., \& Babones, S. J. (2006). Global Social Change: Historical and Comparative Perspectives. Johns Hopkins University Press.

Chauprade, A. (2007). Géopolitique: Constantes et Changements dans l'Histoire. Ellipses Marketing.

Chubin, D. (1976, September). State of the Field The Conceptualization of Scientific Specialties. Sociological Quarterly, 17(4), 448-476. https://doi.org/10.1111/j.1533-8525.1976.tb01715.x

Cohen, B. J. (2008). International Political Economy: An Intellectual History. Princeton University Press.

Cohen, D. (2011). La Mondialisation et ses ennemis,. Paris: Pluriel.

Cohoy, F. (1999). Une histoire du marketing. La Découverte.

Colic-Peisker, V. (2010). Free floating in the cosmopolis? Exploring the identity-belonging of transnational knowledge workers. Global Networks, 10(4), 467-488. https://doi.org/10.1111/j.1471-0374.2010.00298.x

Cooper, A. F., Hughes, C. W., \& De Lombaerde, P. (2007). Regionalisation and Global Governance: The Taming of Globalisation?. Routledge.

Coriat, B., Petit, P., \& Schmeder, G. (2006). The Hardship of Nations: Exploring the Paths of Modern Capitalism. Edward Elgar Pub.

Cuche, D. (2004). La notion de culture dans les sciences sociales. La Découverte.

de Rosnay, J. (2014). Le Macroscope. Vers une vision globale. Points.

Dembinski, P. (2008). Finance servante ou finance trompeuse. Paris: Parole et Silence (Desclée de Brouwer).

Deroin, V. (2011). Approche statistique européenne de la culture: Synthèse des travaux européens ESSnet-Culture, 2009-2011. Ministère de la Culture - DEPS. Culture études. https://doi.org/10.3917/cule.118.0001

Devaney, R. (2003). An Introduction to Chaotic Dynamical Systems (2nd ed.). CRC Press.

Douki, C., \& Minard, P. (2007). Histoire globale, histoires connectées: un changement d'échelle historiographique? Revue d'histoire moderne et contemporaine, 5(54-4bis), 7-21. https://doi.org/10.3917/rhmc.545.0007

Dufoix, S. (2012). La dispersion: Une histoire des usages du mot diaspora. Editions Amsterdam.

Dupin, É. (2017). La France identitaire: Enquête sur la réaction qui vient. Cahiers libres.

Duterme, B. (2014). La Rébellion qui dure. Points de vue du Sud. Paris: Syllepse.

Esping-Andersen, G. (1999). Social Foundations of Postindustrial Economies. Oxford University Press. https://doi.org/10.1093/0198742002.001.0001

Florida, R., \& Boyett, M. (2002). The Rise of the Creative Class: And How It's Transforming Work, Leisure, Community, and Everyday Life. New York: Basic Books. 
Forrester, J. W. (1980). Principes des systèmes. PUL/CERG.

Friedman, D. (1998). Evolutionary economics goes mainstream: A review of the theory of learning in games. Journal of Evolutionary Economics, 8(4), 423-432. https://doi.org/10.1007/s001910050071

Friedman, D. (1998, March). On economic applications of evolutionary game theory. Journal of Evolutionary Economics, Volume 8(Issue 1), 15-43. https://doi.org/10.1007/s001910050054

Fukuyama, F. (1992). La fin de l'Histoire et le dernier homme. Flammarion.

Gadrey, J., \& Jany-Catrice, F. (2012). Les nouveaux indicateurs de richesse. La Découverte.

George, F. H. (1976). Cybernetics. Teach Yourself Books.

Giddens, A. (2002). Runaway World: How Globalization is Reshaping Our Lives. Routledge.

Gleick, J. (1997). Chaos: Making a New Science. Vintage.

Golub, P. (2011). Une autre histoire de la puissance américaine. Seuil.

Gramsci, A., Hoare, Q., \& Geoffrey, S. N. (1971). Selections from the Prison Notebooks. International Publishers Co.

Granovetter, M. (1985). Economic Action and Social Structure: The Problem of Embeddedness. American Journal of Sociology, 95(3), 481-510. https://doi.org/10.1086/228311

Grataloup, C. (2010). Géohistoire de la mondialisation: Le temps long du monde. Armand Colin.

Graz, J.-C. (2013). La gouvernance de la mondialisation. La Découverte.

Grewal, D. (2009). Network Power: The Social Dynamics of Globalization. Yale University Press.

Hannerz, U. (1991). Cultural Complexity: Studies in the Social Organization of Meaning. Columbia University Press.

Hariss, J. (2002, March). The Case for Cross-Disciplinary Approaches in International Development. World Development, 30(3), pp. 487-496. https://doi.org/10.1016/S0305-750X(01)00115-2

Harlé, E., \& Jouanneault, J.-D. (1984). L'Entreprise en tant que Système. Presses Universitaires de Lyon.

Harvard Business Review. (2008). Managing Crises: Expert Solutions to Everyday Challenges. Harvard Business Review Press.

Hasselblatt, B., \& Katok, A. (2003). A First Course in Dynamics: with a Panorama of Recent Developments. Cambridge University Press. https://doi.org/10.1017/CBO9780511998188

Heilbron, J., Guilhot, N., \& Jeanpierre, 1. (2009). Vers une histoire transnationale des sciences sociales. Sociétés contemporaines, 1(73), 121-145. https://doi.org/10.3917/soco.073.0121

Holton, R. J. (2008). Global Networks. Palgrave Macmillan.

Huntington, S. P. (2005). Le choc des civilisations. Odile Jacob.

Jacobs, J. A., \& Frickel, S. (2009). Interdisciplinarity: A Critical Assessment. Annual Review of Sociology, 35(1), 43-65. https://doi.org/10.1146/annurev-soc-070308-115954

Jaffrelot, C. (2008). L'enjeu mondial. Les pays émergents. Les Presses de Sciences Po.

Kagan, R. (2003). La Puissance et la Faiblesse. Plon - Omnibus.

Kanbur, R. (2002). Economics, Social Science and Development. World Development, 30(3), 477-486. https://doi.org/10.1016/S0305-750X(01)00117-6

Katz, D., \& Kahn, R. L. (1978). The Social Psychology of Organizations. Wiley.

Kauffman, S. A. (1993). The Origins of Order: Self-organization and Selection in Evolution. Oxford University Press.

Keck, F. (2010). Un monde grippé. Paris: Flammarion.

King, D., \& Le Galès, P. (2011). Sociologie de l'État en recomposition. Revue française de sociologie, 52, 453-480. https://doi.org/10.3917/rfs.523.0453

Klein, J. T. (1991). Interdisciplinarity: History, Theory, \& Practice. Wayne State University Press. 
Klein, J. T. (1996). Crossing Boundaries: Knowledge, Disciplinarities, and Interdisciplinarities (Knowledge, Disciplinarity \& Beyond). University of Virginia Press.

Klein, J. T. (2006, August). Resources for Interdisciplinary Studies. Change The Magazine of Higher Learning, 38(2), 50-56. https://doi.org/10.3200/CHNG.38.2.50-56

Kleinberg, E. (2008). Interdisciplinary Studies at a Crossroads. (A. o. Universities, Ed.) Liberal Education, 94(1). Available at: https://wesscholar.wesleyan.edu/div1 facpubs/99

Koch, O., \& Mattelart, T. (2016). Géopolitique des télévisions transnationales d'information. Mare \& Martin.

Kotler, P., \& Caslione, J. A. (2009). Chaotics: The Business of Managing and Marketing in the Age of Turbulence. New York: AMACOM.

Kuhn, T. (1996). The Structure of Scientific Revolutions (3rd ed.). University of Chicago Press. https://doi.org/10.7208/chicago/9780226458106.001.0001

Kunz, R. (2011). The Political Economy of Global Remittances: Gender, Governmentality and Neoliberalism. London: Routledge.

Lacoste, Y. (2006). Géopolitique: La longue histoire d'aujourd'hui. Larousse.

Lacoste, Y. (2014). La géographie, ça sert, d'abord, à faire la guerre. La Découverte.

Lechner, F. J., \& Boli, J. (2011). The Globalization Reader. Wiley-Blackwell.

Lévy, J., Poncet, P., et al. (2008). L'invention du monde: Une géographie de la mondialisation. Les Presses de Sciences Po.

Lordon, F. (2009). La crise de trop - Reconstruction d'un monde failli. Fayard.

Lorenz, E., \& Valeyre, A. (2004). Organisational Change in Europe: National Models or the Diffusion of a New "One Best Way"? DRUID Working Papers 04-04. DRUID, Copenhagen Business School, Department of Industrial Economics and Strategy/Aalborg University, Department of Business Studies.

Lowe, A. (1951, December). On the Mechanistic Approach in Economics. Social Research, Volume 18(4), 403-434. Available at: http://www.jstor.org/stable/40982331

Luttwak, E. N. (1990). From Geopolitics to Geo-Economics. The National Interest, 17-24.

Marchal, A. (1956). Méthode scientifique et science économique. Tome II, Problèmes actuels de l'analyse économique: ses approches fondamentales. Revue économique, 7(3), 483-488.

Martel, F. (2010). Mainstream. Enquête sur cette culture qui plaît à tout le monde. Paris: Flammarion.

Mattelart, A. (2007). Diversité culturelle et mondialisation. La Découverte.

Mattelart, A. (2009). Histoire de la société de l'information. La Découverte.

Mattelart, A., \& Neveu, E. (2008). Introduction aux Cultural Studies. La Découverte.

Mattli, W., \& Woods, N. (2009). The Politics of Global Regulation. Princeton University Press. https://doi.org/10.1515/9781400830732

Maturana, H. R., \& Varela, F. J. (1980). Autopoiesis and Cognition: The Realization of the Living. D. Reidel Publishing Company. https://doi.org/10.1007/978-94-009-8947-4

Mitroff, I. I., \& Silvers, A. (2009). Dirty Rotten Strategies: How We Trick Ourselves and Others into Solving the Wrong Problems Precisely. Stanford Business Books.

Moore, W. E. (1966). Global Sociology: The World as a Singular System. American Journal of Sociology, Volume 71(5), 475-482. https://doi.org/10.1086/224165

Nissani, M. (1997). Ten cheers for interdisciplinarity: The case for interdisciplinary knowledge and research. The Social Science Journal, 34(2), 201-216. https://doi.org/10.1016/S0362-3319(97)90051-3

Noiriel, G. (2007). A quoi sert "l'identité nationale"? Marseille: Agone.

Orléan, A. (2009). De l'euphorie à la panique: penser la crise financière. Rue d'Ulm.

Overbeek, H., \& van Apeldoorn, B. (2012). Neoliberalism in Crisis. Palgrave Macmillan. https://doi.org/10.1057/9781137002471

Palan, R. (2000). Global Political Economy: Contemporary Theories. Routledge. 
Palmade, G., et al. (1967). L'économique dans les sciences humaines. L'Homme et la société, 5(1), 226-227.

Passet, R. (1996). L'économique et le vivant. Economica.

Pekelis, V. D. (1974). Cybernetics A to Z. Mir Publishers.

Perez, C. (2003). Technological Revolutions and Financial Capital: The Dynamics of Bubbles and Golden Ages. Edward Elgar Pub.

Rainelli, M. (2011). L' Organisation mondiale du commerce. La Découverte.

Reinert, E. (2008). How Rich Countries Got Rich . . and Why Poor Countries Stay Poor. PublicAffairs.

Robertson, R., \& Scholte, J. A. (2006). Encyclopedia of Globalization. Routledge.

Rodrik, D. (2011). The Globalization Paradox: Democracy and the Future of the World Economy. W. W. Norton \& Company. https://doi.org/10.1355/ae28-3k

Rosenberg, J. (2005). 2005: Globalization Theory: A Post Mortem. International Politics, 42, 2-74. https://doi.org/10.1057/palgrave.ip.8800098

Rosenberg, N., \& Birdzell, 1. E. (1987). How the West Grew Rich: The Economic Transformation of the Industrial World. Basic Books.

Rowlatt, J. (2012). BBC NEWS. Retrieved from Goldman's top economist: there is no economic crisis: http://www.bbc.com/news/business-17447773

Sassen, S. (2007). A Sociology of Globalization. W. W. Norton \& Company.

Schuurman, F. J. (2000). Paradigms lost, paradigms regained? Development studies in the twenty-first century. Third World Quarterly, 21, 7-20. https://doi.org/10.1080/01436590013198

Seeger, M.W., Sellnow, T.L., \& Ulmer, R. R. (1998). Communication, Organization, and Crisis. Communication Yearbook 21, 231-275. https://doi.org/10.1080/23808985.1998.11678952

Selchow, S., Kaldor, M., \& Moore, H. L. (2012). Global Civil Society 2012: Ten Years of Critical Reflection. Palgrave Macmillan UK. https://doi.org/10.1057/9780230369436

Sen, A. (2011). Development as Freedom. Anchor; Reprint edition.

Senge, P. M. (1994). The Fifth Discipline Fieldbook: Strategies and Tools for Building a Learning Organization. Crown Business.

Senge, P. M. (1999). The Dance of Change: The challenges to sustaining momentum in a learning organization (The Fifth Discipline). Crown Business.

Senge, P. M. (2006). The Fifth Discipline: The Art \& Practice of The Learning Organization. Doubleday.

Servet, J.-M. (2010). Le grand renversement: De la crise au renouveau solidaire. Desclée De Brouwer.

Simmons, B., Dobbin, F., \& Garrett, G. (2008). The Global Diffusion of Markets and Democracy. Cambridge University Press. https://doi.org/10.1017/CBO9780511755941

Sinclair, T. (2012). Global Governance. Polity.

Stehr, N., \& Weingart, P. (2000). Practising Interdisciplinarity. University of Toronto Press, Scholarly Publishing Division.

Strange, S. (1996). The Retreat of the State: The Diffusion of Power in the World Economy. Cambridge University Press. https://doi.org/10.1017/CBO9780511559143

Stuart, H. (2005). Disciplinary hegemony meets interdisciplinary ascendancy: Can interdisciplinary/integrative studies survive, and, if so, how. Issues in integrative studies, 23, 1-37. Retrieved from http://hdl.handle.net/10323/4435

Sumner, A., \& Tribe, M. A. (2008). International Development Studies: Theories and Methods in Research and Practice. SAGE Publications Ltd. https://doi.org/10.4135/9781446279397

Théret, B. (1992). Régimes économiques de l'ordre politique: esquisse d'une théorie régulationniste des limites de l'Etat. Paris: PUF.

Toulmin, S. (1985). The Return to Cosmology: Postmodern Science and the Theology of Nature. University of California Press. 
Toulmin, S. (1992). Cosmopolis: The Hidden Agenda of Modernity. The University of Chicago Press.

UNESCO. (2013). Rapport sur l'économie créative. Édition spéciale. New York/Paris: Nations unies/PNUD/Unesco.

UNESCO. (2015). Re Penser les politiques culturelles: 10 ans de promotion de la diversité des expressions culturelles pour le développement. UNESCO.

Venette, S. J. (2008). Risk as an Inherent Element in the Study of Crisis Communication. Southern Communication Journal, 73(3), 197-210. https://doi.org/10.1080/10417940802219686

von Bertalanffy, L. (2012). Théorie générale des systèmes. Dunod.

Warnier, J.-P. (2008). La mondialisation de la culture. La Découverte.

Weiner, N. (1961). Cybernetics: or Control and Communication in the Animal and the Machine (2nd ed.). MIT Press. https://doi.org/10.1037/13140-000

Weingart, P., \& Padberg, B. (2014). University Experiments in Interdisciplinarity: Obstacles and Opportunities. Transcript Verlag. https://doi.org/10.14361/transcript.9783839426166

White, H. (2002). Combining Quantitative and Qualitative Approaches in Poverty Analysis. World Development, 30(3), 511-522. https://doi.org/10.1016/S0305-750X(01)00114-0

\section{In Greek}

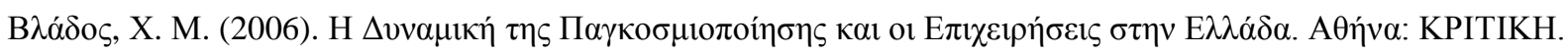

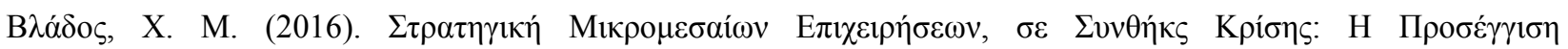

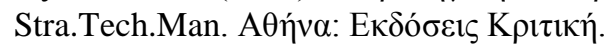

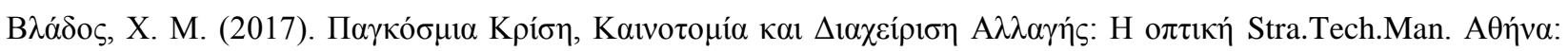

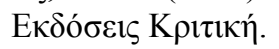

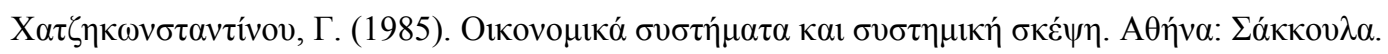

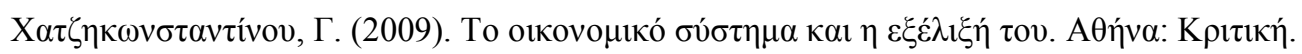

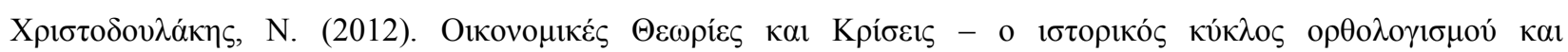

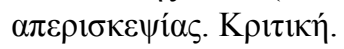

